\title{
ADSORPTIVE APPROACH ON NEPHOLOMETRIC STUDY OF PAINT EFFLUENT USING TYMPANOTONOS FUSCATUS EXTRACT
}

\author{
Ifechukwu G. Ezemagu ${ }^{1}$, Matthew C. Menkiti ${ }^{12^{*}}$, Victor I. Ugonabo ${ }^{1}$ and Mathew C. Aneke ${ }^{3}$ \\ ${ }^{1}$ Department of Chemical Engineering, Nnamdi Azikiwe University, Awka, Nigeria \\ ${ }^{2}$ Water Resources Center, Texas Tech University, Lubbock, Texas, USA \\ ${ }^{3}$ Department of Chemical Engineering, University of Hull, UK
}

(Received December 2, 2014; revised August 21, 2016)

\begin{abstract}
Adsorptive study of paint effluent coagulation using T. fuscatus coagulant (TFC) is investigated. Effects of $\mathrm{pH}$, dose, time, and temperature were investigated. Functional group, crystalline, morphology and thermal characteristics of samples were determined. Equilibrium data were analysed by Langmuir, Freundlich, Temkin, Frumkin, and Dubinin-Radushkevich (D-R) isotherms. Kinetic data were fitted to reversible first order, pseudo-first-order, pseudo-second-order, Elovich, intra-particle diffusion and Boyd kinetic models. Process Gibbs free energy $\left(\Delta \mathrm{G}^{\circ}\right)$, enthalpy $\left(\Delta \mathrm{H}^{\circ}\right)$ and the entropy $\left(\Delta \mathrm{S}^{\circ}\right)$ were evaluated. The process was best described by Langmuir isotherm $\left(\mathrm{R}^{2}>0.99 ; \mathrm{X}^{2}<0.6\right.$; SSE $\left.<0.7\right)$. Pseudo second order best fitted the kinetic data. The process was spontaneous, feasible and endothermic. $97 \%$ optimal removal was achieved at $\mathrm{pH}$ 5. Tympanotonos fuscatus extract has potential for application as an effective coagulant while showing significant component of adsorptive phenomenon
\end{abstract}

KEY WORDS: Paint effluent, Coagulation/flocculation, Adsorption, Tympanotonos fuscatus

\section{INTRODUCTION}

Industrialization has accelerated pollution in the aquifers, such that much of the water requires a form of treatment before use. Paint effluent (PE) contributes to this pollution. PE is turbid and contains highly toxic compounds that harm humans, fishes and contaminates the food chain if drained into soil $[1,2]$. Thus, the treatment and safe disposal of PE become vital for environmental conservation.

The treatment methods are selective and include chemical precipitation, adsorption, ion exchange and coagulation/flocculation, which had been implemented using varieties of coagulants and effluents [3-7]. The advantage is that coagulation is robust, relatively low energy demand, needs low operator skill and active in natural organic matter (NOM), inorganics and turbidity enriched effluent.

Factors that affect coagulation include raw effluent characteristics, temperature, $\mathrm{pH}$, dosage, etc [8]. Traditionally, coagulation-flocculation has been achieved using inorganic alum and iron chloride. Problems with their usage include poor performance in low-temperature water and high sludge volume generation and link to Alzheimer's disease in human [9]. These problems motivated the use of extracts from snail shell, nirmali seeds (Strychnos potatorum), Moringa oleifera, tannin, cactus [10] and T. fuscatus shell.

T. fuscatus shell (TFS) is of natural non-toxic chitin, which is a major component of the shells of crustacean. It is enriched with carbohydrate biopolymer [11, 12]. TFS abound as wastes in Nigeria, making it attractive as biomaterials. T. fuscatus coagulant (TFC), obtained by deacetylation of chitin $[11,12]$, has been applied in varying effluents and could be extended to PE.

Currently, there is little study focus on adsorptive component of bio-coagulation, hence this report contributes towards bridging this gap. Coagulation data were analysed in the light of

${ }^{*}$ Corresponding author. E-mail: cmenkiti@yahoo.com 
adsorption isotherm, kinetics and thermodynamics. Effects of process variables were evaluated. Instrumental and physiochemical characterization of sample were conducted.

\section{EXPERIMENTAL}

Material collection and preparation

PE and TFS were obtained from Onitsha, Anambra State, Nigeria. PE was prepared and stored $[13-15]$. TFS was processed to TFC $[11,16]$. The processing involved majorly: deproteinization, demineralization and deacetylation to produce TFC.

Material characterization

Paint effluent. Standard APHA methods [15] were applied for physiochemical characterization of PE.

T. fuscatus shell. Yield/weight loss, bulk density, ash content, oil content, moisture content and protein content were determined as reported elsewhere [17].

Instrumental characterization of bio-coagulant. Instrumental characterization was conducted using Thermo Nicolet Nexus 470/670/870 FTIR Spectrophotometer, Philips X PERT X-RAY diffractometer, Zeiss Evo®MA 15 EDX/WDS microscope and (TGA - Q50 and DSC - Q200) theremogravimetric units.

\section{Coagulation and flocculation experiment}

Effect of coagulant dosage on efficiency. Initial $\mathrm{pH}$ and turbidity of PE were determined. (i) $1000 \mathrm{~mL}$ of the PE contained in 10 different $1000 \mathrm{~mL}$ GG-17 beakers (10 cm diameter) were dosed with $0.50-5 \mathrm{~g} / \mathrm{L}$ of TFC. (ii) Using magnetic stirrer, the mixture of the effluent and coagulant contained in the $1000 \mathrm{~mL}$ beakers were subjected to rapid mixing at $250 \mathrm{rpm}(\mathrm{G}=$ $\left.550 \mathrm{~s}^{-1}\right)$ for $2 \mathrm{~min}$, followed by slow mixing at $30 \mathrm{rpm}\left(\mathrm{G}=22 \mathrm{~s}^{-1}\right)$ for $20 \mathrm{~min}$. (iii) At the end of slow mixing, the treated PE was allowed to settle for $30 \mathrm{~min}$. (iv) At $30 \mathrm{~min}$ settling time, 20 $\mathrm{mL}$ of the supernatant was respectively pipetted from $2 \mathrm{~cm}$ depth into $50 \mathrm{~mL}$ turbidity cuvette and residual turbidity measured for each dosage for the determination of optimum dosage.

Effect of pH variation on efficiency. The optimum dosage obtained from results was used for the evaluation of $\mathrm{pH}$ effect. The following steps were involved: (i) Equal optimum dosages of TFC were dosed into 9 different beakers each containing $1000 \mathrm{~mL}$ of PE sample. The samples $\mathrm{pH}$ was adjusted to 2, 3, 4, 5, 6, 7, 8, 9 and 10 using $0.1 \mathrm{M} \mathrm{H}_{2} \mathrm{SO}_{4}$ and $0.1 \mathrm{M} \mathrm{NaOH}$ just before dosing of the coagulant sample. (ii) Steps (ii-iv) in the previous subsection were repeated with respect to $\mathrm{pH}$ variation, leading to determination of optimum $\mathrm{pH}$.

Temporal variation of $Q_{t}$ with dosage. (i) Steps (i)-(ii) were repeated. (ii) During the settling period following the ceasing of slow mixing, $20 \mathrm{~mL}$ of the supernatant was respectively pipetted from $2 \mathrm{~cm}$ depth into $50 \mathrm{~mL}$ turbidity cuvette at 3, 5, 10,15, 20, 25 and $30 \mathrm{~min}$. The residual turbidity of each supernatant collected was measured and converted to $\mathrm{mg} / \mathrm{L}$ on multiplying turbidity by a conversion factor of 2.35 [13]. 
Analytical method

The adsorptive capacity, $\mathrm{q}_{\mathrm{t}}(\mathrm{mg} / \mathrm{g})$, and the percentage removal, \% Rem, were calculated using Eqs. 1 and 2, respectively.

$\mathrm{q}_{\mathrm{t}}=\frac{C o-C t)}{M} x V$

$\%$ Rem $=\frac{C o-C t}{C o} \times 100$

where $\mathrm{C}_{\mathrm{o}}, \mathrm{C}_{\mathrm{t}} \mathrm{V}$ and $\mathrm{M}$ are initial constant effluent concentration $(\mathrm{mg} / \mathrm{L})$, effluent concentration at any time, $\mathrm{t}$; volume of effluent (l) and mass of coagulant $(\mathrm{g})$, respectively.

\section{RESULTS AND DISCUSSION}

\section{Characterization results}

Physiochemical and biological characteristics. Characteristics of TFS and PE along with the regulatory standard are presented in Tables 1 and 2, respectively. Total suspended solid, total dissolved solid and total solid of PE were relatively significant to support coagulation study. Meanwhile, the protein content of TFS was substantial to suggest TFS as precursor.

Table 1. Proximate analysis of TFS.

\begin{tabular}{|l|l|}
\hline Parameter & Value \\
\hline Yield (\%) & 80 \\
\hline Weight loss (\%) & 20 \\
\hline Bulk density (g/mL) & 0.12 \\
\hline Ash content (\%) & 4.98 \\
\hline Oil content (\%) & 10 \\
\hline Moisture content (\%) & 4.5 \\
\hline Protein $(\%)$ & 17.7 \\
\hline
\end{tabular}

Table 2. PE characteristics and NESRA* standard.

\begin{tabular}{|l|l|l|}
\hline Parameter & Value & NESRA \\
\hline TSS & $2679 \mathrm{mg} / \mathrm{L}$ & $100 \mathrm{mg} / \mathrm{L}$ \\
\hline pH & 8 & $6-8$ \\
\hline TDS & $1365 \mathrm{mg} / \mathrm{L}$ & $1200 \mathrm{mg} / \mathrm{L}$ \\
\hline TS & $4044 \mathrm{mg} / \mathrm{L}$ & $1300 \mathrm{mg} / \mathrm{L}$ \\
\hline
\end{tabular}

"National Environment Standards Regulations (NESRA), Nigeria.

FTIR spectra analyses. FTIR spectrum of TFC shown in Figure 1 exhibits 19 discernable peaks at $600-4000 \mathrm{~cm}^{-1}$ with a threshold of 1.17 . In Figure 1, peaks at 3850 to $3593 \mathrm{~cm}^{-1}$ could be attributed to hydroxyl $(\mathrm{O}-\mathrm{H})$ groups. Peak at $3296 \mathrm{~cm}^{-1}$ is linked to secondary amide $(\mathrm{N}-\mathrm{H})$ groups. Peaks at 2916 and $2850 \mathrm{~cm}^{-1}$ are for aliphatic hydrocarbon. Aliphatic rings $(\mathrm{C}=\mathrm{C}$ stretching, $\mathrm{NH}_{2}$ scissoring, azo compound and $\mathrm{N}-\mathrm{H}$ bending) were peaked at 1634 to $1443 \mathrm{~cm}^{-1}$. Peaks at 1082,1068 and $1032 \mathrm{~cm}^{-1}$ are for C-O stretching. Amine and alkyne peaks at 909,855 , 781,712 and $699 \mathrm{~cm}^{-1}$ are for $\mathrm{N}-\mathrm{H}$ stretching, $\mathrm{NH}_{2}$ wagging and twisting, $\mathrm{N}-\mathrm{H}$ wagging and $=\mathrm{C}-\mathrm{H}$ bending, respectively [18].

XRD pattern. The XRD pattern of TFC shown in Figure 2 depicts eleven clear peaks. Some of the crystal peaks were shifted towards left-right axes, resulting from expansion or contraction of 
the sample. The peaks indicated that the atomic structure of TFC was of primitive lattice structure.

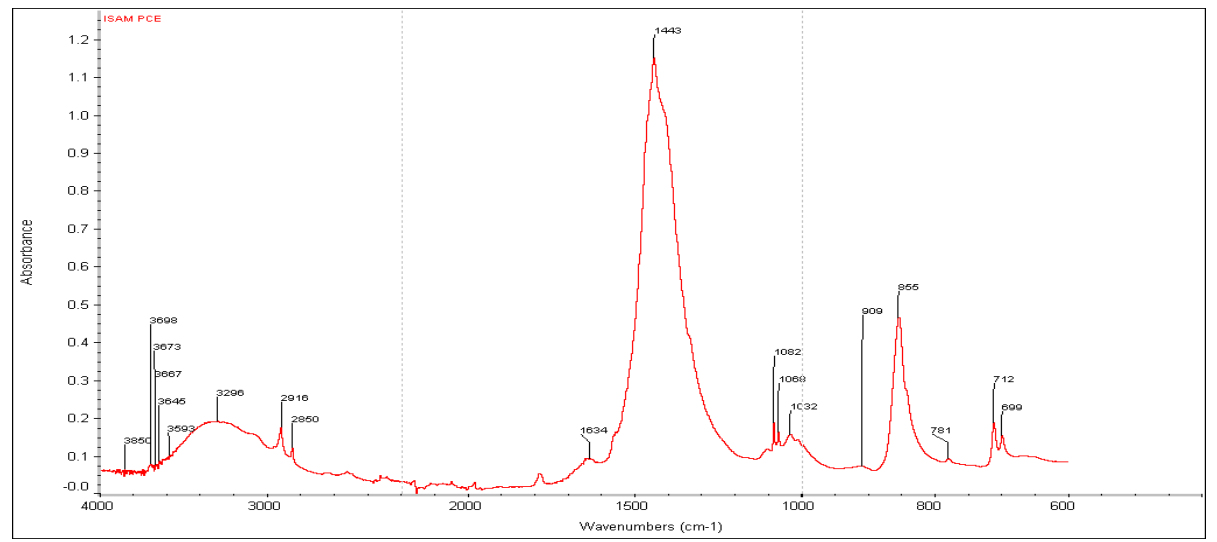

Figure 1. FTIR spectrum of TFC.

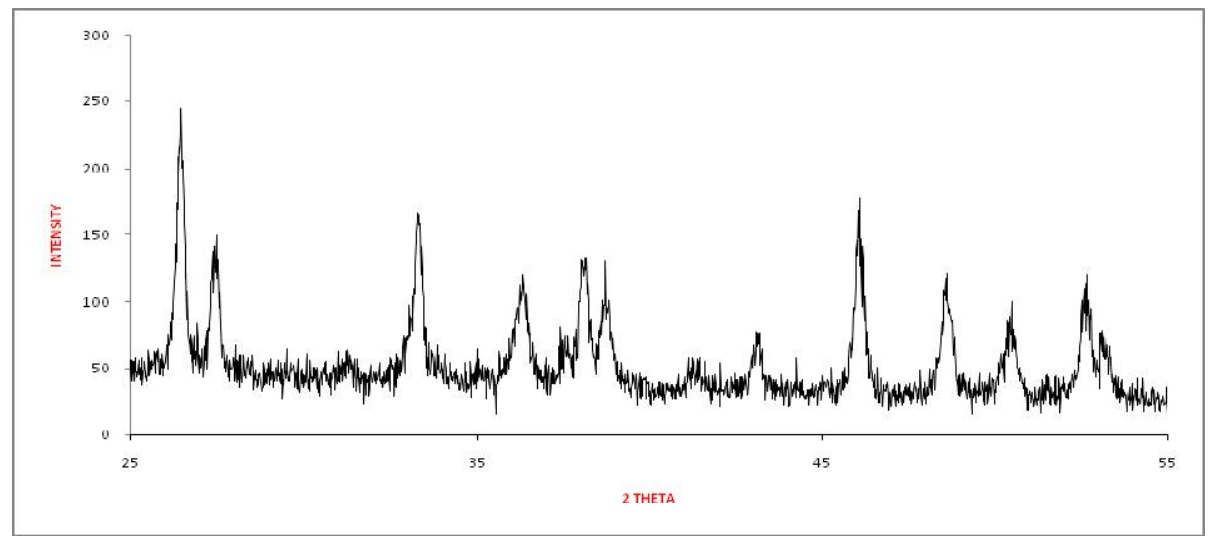

Figure 2. XRD pattern of TFC.

Thermo-gravimetric and differential scanning calorimetric analyses. The TGA and DSC curves for TFC are presented in Figure 3. The weight loss of the material could result from chemical reaction (decomposition, combustion) and physitransition (evaporation, desorption, drying) [19, 20]. Figure $3 \mathrm{a}$ indicates that the final residual mass was $3.26 \mathrm{mg}$ ( $94.1 \%$ original weight). In Figure $3 \mathrm{a}$, the initial weight loss resulted from the internal moisture and gaseous losses [21]. The second phase weight loss resulted from the decomposition of the labile component in the samples. Figure $3 \mathrm{~b}$ indicates phase transition involving two eutectic peaks at $37.5-297^{\circ} \mathrm{C}$ for enthalpy of $11.4 \mathrm{~kJ} / \mathrm{mol}$. The endothermic densification took place at $112.5-187.5^{\circ} \mathrm{C}$ (Figure $3 \mathrm{~b})$. Figure $3 \mathrm{~b}$ indicates glass transition temperature within $31.25-37.5{ }^{\circ} \mathrm{C}$ for the coiling of carbon chain necessary for spontaneous densification [21, 22]. Conclusively, Figure 3 suggested thermal operational stability at activation energy of $15.0 \mathrm{~kJ} / \mathrm{mol}$. Figure $3 \mathrm{~b}$ indicated exothermicity. 

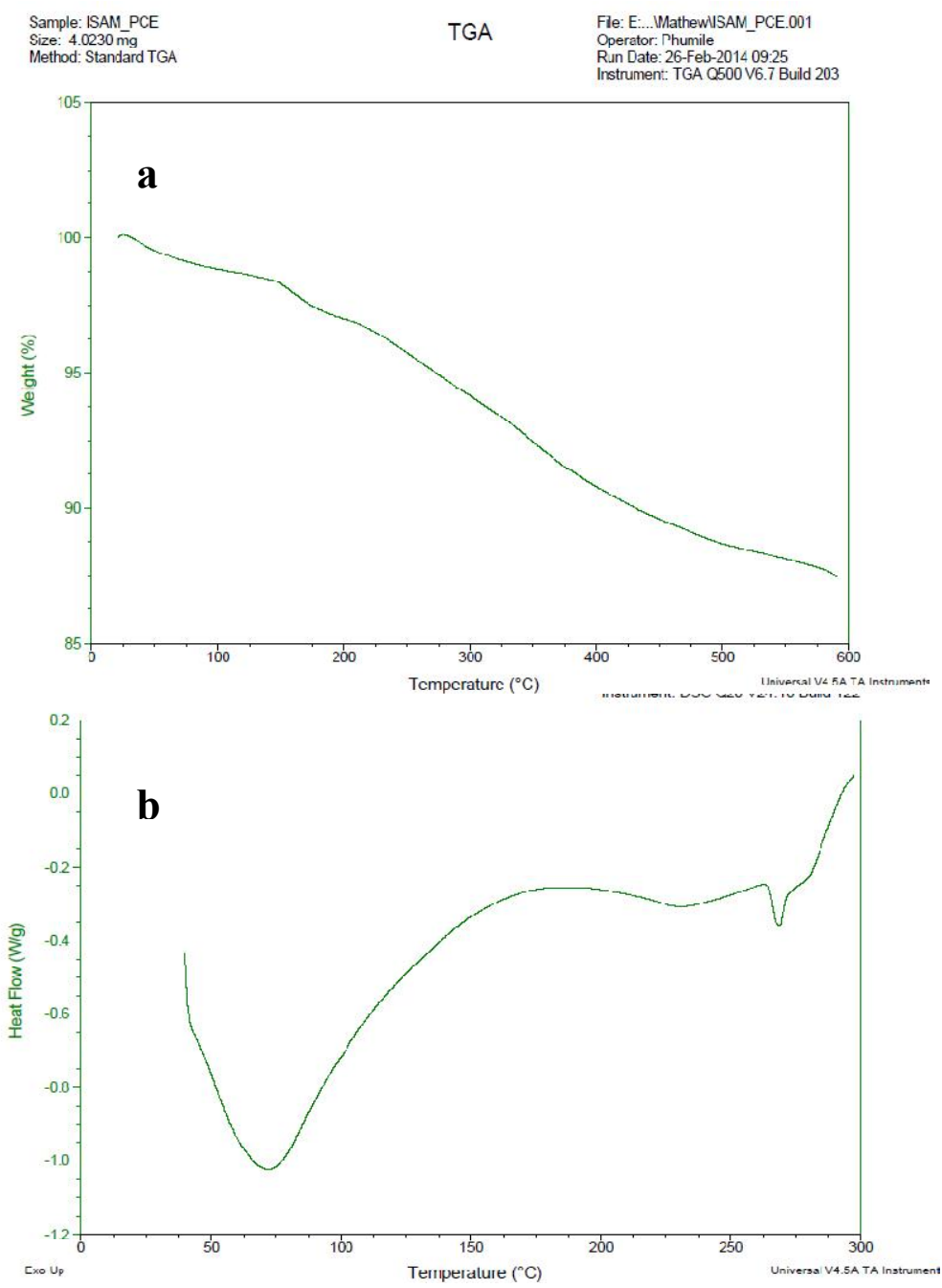

Figure 3. (a) TGA and (b) DSC of TFC.

SEM analyses. The surface morphology of TFC is shown in Figure 4. The images in Figure 4 appear to be white field with porous but irregular network structure. While Figure 4a indicates the penetrating pores towards the internals of the sample mass, Figure $4 \mathrm{~b}$ shows the discrete multiple pores of the sample. The prevalence of these pores activated the binding affinity among the coagulant's pores surfaces and effluent's particles. 


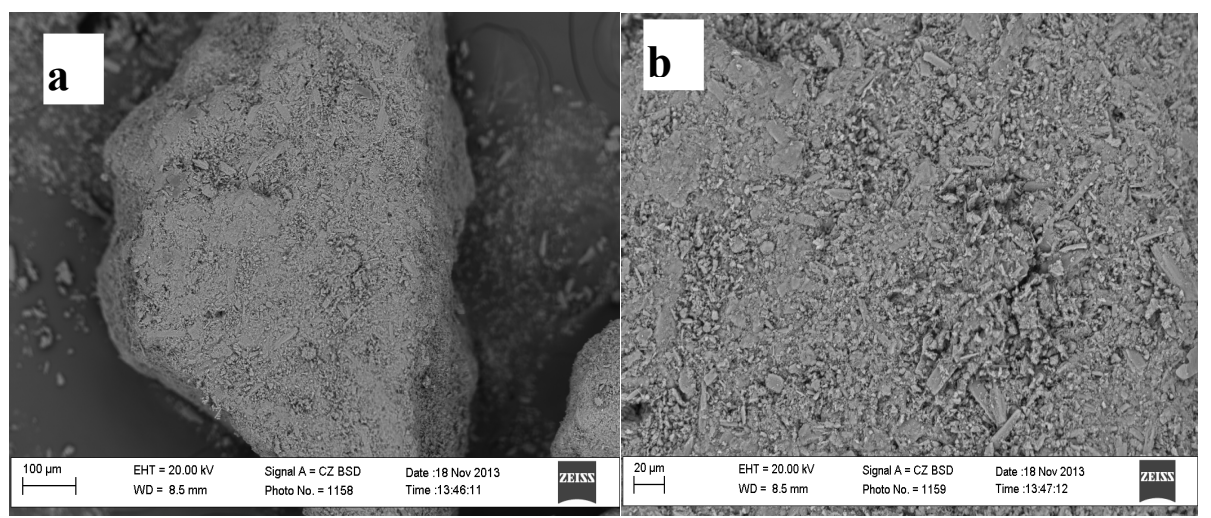

Figure 4. SEM micrograph of TFC.

Factors sensitivity analysis

Effect of TFC dosage on particle removal efficiency. Figure 5 indicates (at natural $\mathrm{pH}$ ) that the efficiency increased from $4 \%$ at $0.5 \mathrm{~g} / \mathrm{L}$, peaking at $46.6 \%$ for $2 \mathrm{~g} / \mathrm{L}$ and thereafter decreased to $6 \%$ at $5 \mathrm{~g} / \mathrm{L}$. The increase resulted from increased supply of coagulant's charged species (mainly +ve charges) that incrementally destabilized the effluent charged species (mainly -ve charges), thus ensuring progressive particle removal as dosage increased from 0.5 to $2 \mathrm{~g} / \mathrm{L}$. Furthermore, the decrease after $2 \mathrm{~g} / \mathrm{L}$ resulted from sustained re-stabilisation following excessive supply of +ve charged species due to overdosing after $2 \mathrm{~g} / \mathrm{L}$, up till $5 \mathrm{~g} / \mathrm{L}$. At $2 \mathrm{~g} / \mathrm{L}$, both charged species equilibrated for optimum performance $[8,23]$. Hence, $2 \mathrm{~g} / \mathrm{L}$ applied for the effect of $\mathrm{pH}$.

Effect of $p H$ on particle removal at $2 \mathrm{~g} / \mathrm{L}$ TFC. The effect of $\mathrm{pH}$ on efficiency for optimum $2 \mathrm{~g} / \mathrm{L}$ TFC is depicted in Figure 6. Figure 6 exhibited alternate decrease and increase in efficiency as the $\mathrm{pH}$ decreased from 9-2. The $\mathrm{pH}$ ranges 3-2 and 8-5 recorded increment in efficiency due to progressive protonation. Conversely, the decrease in efficiency for $\mathrm{pH}$ ranges 9-8 and 5-3 could be explained by net $+v e$ and - ve species induced charge reversal, respectively. Charge reversal results in re-stabilization and coagulation retardation. Optimal $97 \%$ at $\mathrm{pH} 5$ denoted equilibrium in the provision of opposing ions for point of zero charge [23].

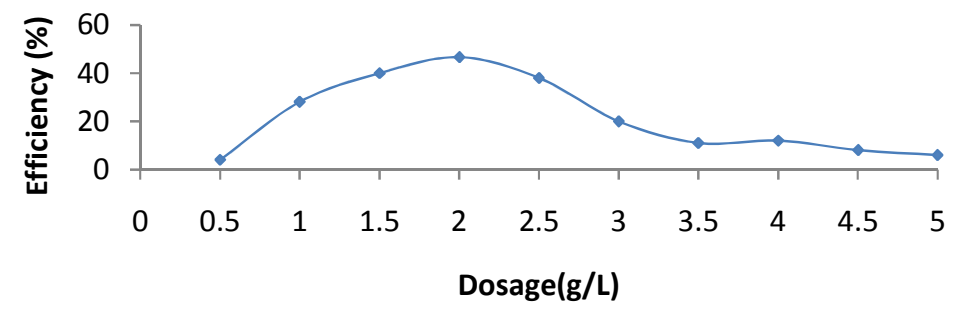

Figure 5. Removal efficiency vs dosage for TFC in PE.

Temporal variation of adsorption capacity for TFC in PE. The $\mathrm{q}_{\mathrm{t}}$ of TFC is shown in Figure 7. It shows that $\sim 90 \%$ of adsorption occurred between 0-20 min; thereafter $q_{t}$ became constant [21]. Meanwhile, Figure 7, demonstrated that $\mathrm{q}_{\mathrm{t}}$ increased with decreasing dosage and increasing 
time. At 0.5 and $5 \mathrm{~g} / \mathrm{L}$, the highest and the lowest values of $\mathrm{q}_{\mathrm{t}}$ were respectively, recorded. $\mathrm{q}_{\mathrm{t}}$ at $0.5 \mathrm{~g} / \mathrm{L}$ increased from 372 to $471 \mathrm{mg} / \mathrm{g}$ for 0 and (20-30) min, respectively. At $5 \mathrm{~g} / \mathrm{L}, \mathrm{q}_{\mathrm{t}}$ increased from 230 to $253 \mathrm{mg} / \mathrm{g}$ for 0 and (20-30) min, respectively.

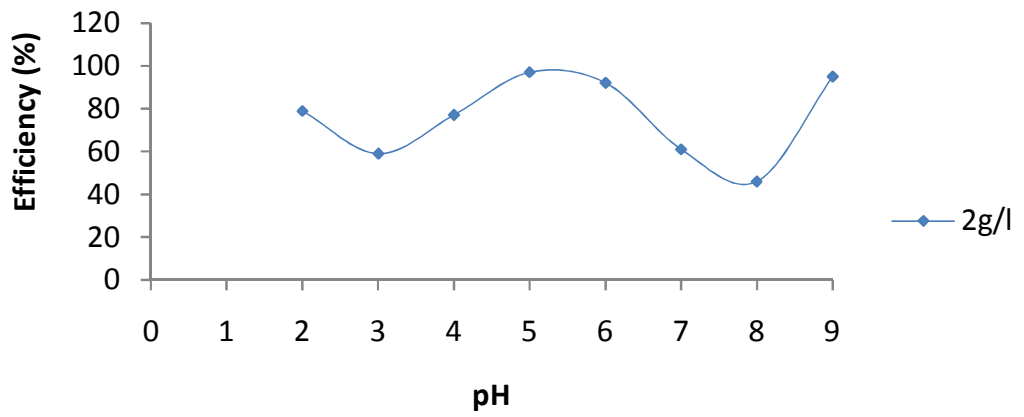

Figure 6. Effect of $\mathrm{pH}$ on particle removal efficiency at $2 \mathrm{~g} / \mathrm{L}$.

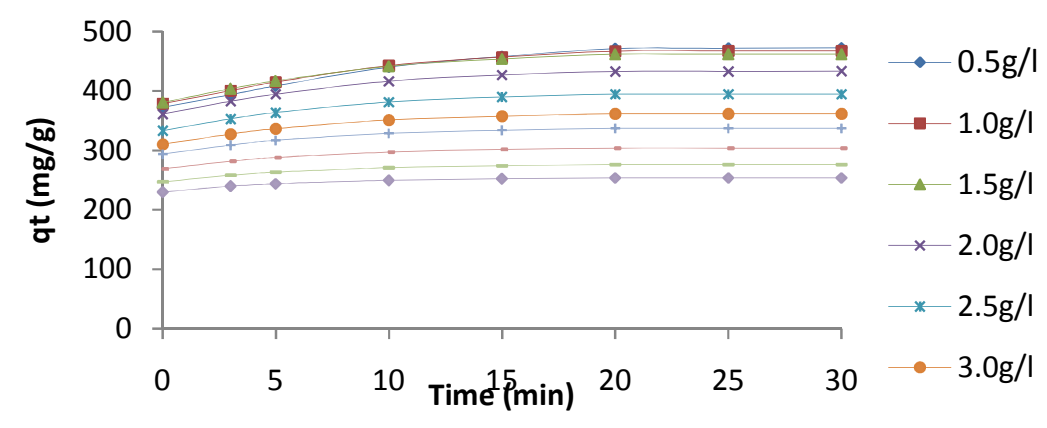

Figure 7. Temporal variation of $\mathrm{q}_{\mathrm{t}} \mathrm{vs}$ time at varying dosage and $\mathrm{pH} 5$ for TFC in PE.

Table 3. The kinetic equation used for analysis of kinetic data.

\begin{tabular}{|c|c|c|c|c|}
\hline KE & Linear form of the equation & Plots made & Eq. No. & Reference \\
\hline RFO & $\ln \left(1-U_{t}\right)=-k_{r}, U_{t}=\left[\left(C_{o^{-}} C_{t}\right) /\left(C_{t}-C_{e}\right)\right], k_{r}=\left(K_{l}+K_{2}\right)$ & $\ln \left[1-U_{t}\right] v s t$ & 3 & 24,25 \\
\hline PFO & $\log \left(q_{e}-q_{t}\right)=\log q_{e}-\left(K_{s} t\right) / 2.303$ & $\log \left(q_{e}-q_{t}\right) v s t$ & 4 & 26 \\
\hline PSO & $t / q_{t}=1 /\left(k^{2} q_{e}^{2}\right)+t / q_{e}$ & $t / q_{t} v s t$ & 5 & 27 \\
\hline ELV & $q_{t}=(1 / \beta) \ln (\alpha \beta)+(1 / \beta) \ln t$ & $q_{t} v s \ln t$ & 6 & 28 \\
\hline
\end{tabular}

Kinetic analysis

Table 3 briefly express the applied kinetic equations and the corresponding plots made. Only pseudo second order plot is shown as Figure 8. The parameters are arrayed in Table 4. Comparison among $\mathrm{R}^{2}$ shown in Table 4 indicated the following order of variation: pseudo second order $>$ reversible first order $>$ pseudo first order $>$ Elovich. Hence, the pseudo-second order has the best correlation. 
Table 4. The kinetic parameters evaluated for TFC in PE at $25^{\circ} \mathrm{C}$ and $\mathrm{pH} 5$.

\begin{tabular}{|c|c|c|c|c|c|c|c|c|c|c|}
\hline \multicolumn{11}{|c|}{ Reversible first order for $T F C$ in $P E$ at $25^{\circ} \mathrm{C}$ and $p H 5$} \\
\hline Dosage & $0.5 \mathrm{~g} / \mathrm{L}$ & $1 \mathrm{~g} / \mathrm{L}$ & $1.5 \mathrm{~g} / \mathrm{L}$ & $2 \mathrm{~g} / \mathrm{L}$ & $2.5 \mathrm{~g} / \mathrm{L}$ & $3 \mathrm{~g} / \mathrm{L}$ & $3.5 \mathrm{~g} / \mathrm{L}$ & $4 \mathrm{~g} / \mathrm{L}$ & $4.5 \mathrm{~g} / \mathrm{L}$ & $5 \mathrm{~g} / \mathrm{L}$ \\
\hline K & 0.167 & 0.173 & 0.181 & 0.118 & 0.191 & 0.193 & 0.197 & 0.195 & 0.196 & 0.198 \\
\hline $\mathrm{R}^{2}$ & 0.9963 & 0.9979 & 0.9986 & 0.9985 & 0.9991 & 0.9996 & 0.9994 & 0.9997 & 0.9997 & 0.9998 \\
\hline \multicolumn{11}{|c|}{ Pseudo first order parameters for TFC in PE at $25^{\circ} \mathrm{C}$ and $\mathrm{pH} 5$} \\
\hline Dosage & $0.5 \mathrm{~g} / \mathrm{L}$ & $1 \mathrm{~g} / \mathrm{L}$ & $1.5 \mathrm{~g} / \mathrm{L}$ & $2 \mathrm{~g} / \mathrm{L}$ & $2.5 \mathrm{~g} / \mathrm{L}$ & $3 \mathrm{~g} / \mathrm{L}$ & $3.5 \mathrm{~g} / \mathrm{L}$ & $4 \mathrm{~g} / \mathrm{L}$ & $4.5 \mathrm{~g} / \mathrm{L}$ & $5 \mathrm{~g} / \mathrm{L}$ \\
\hline $\mathrm{K}_{\mathrm{s}}\left(\mathrm{min}^{-1}\right)$ & 0.0586 & 0.0628 & 0.0676 & 0.0712 & 0.0736 & 0.0754 & 0.0785 & 0.0781 & 0.0791 & 0.0809 \\
\hline $\mathrm{q}_{\mathrm{e}}\left(\mathrm{mg} \cdot \mathrm{g}^{-1}\right)$ & 572 & 561.5 & 544 & 507 & 480 & 489 & 406 & 363 & 325 & 294 \\
\hline$R^{2}$ & 0.9853 & 0.9901 & 0.9923 & 0.9925 & 0.9946 & 0.9963 & 0.9961 & 0.9978 & 0.9983 & 0.9997 \\
\hline \multicolumn{11}{|c|}{ Pseudo second order parameter for TFC in PE at $25^{\circ} \mathrm{C}$ and $\mathrm{pH} 5$} \\
\hline Dosage & $0.5 \mathrm{~g} / \mathrm{L}$ & $1 \mathrm{~g} / \mathrm{L}$ & $1.5 \mathrm{~g} / \mathrm{L}$ & $2 \mathrm{~g} / \mathrm{L}$ & $2.5 \mathrm{~g} / \mathrm{L}$ & $3 \mathrm{~g} / \mathrm{L}$ & $3.5 \mathrm{~g} / \mathrm{L}$ & $4 \mathrm{~g} / \mathrm{L}$ & $4.5 \mathrm{~g} / \mathrm{L}$ & $5 \mathrm{~g} / \mathrm{L}$ \\
\hline $\begin{array}{l}\mathrm{K}_{2} \\
(\mathrm{~g} / \mathrm{mg} / \mathrm{min})\end{array}$ & 0.0021 & 0.002 & 0.0021 & 0.0023 & 0.0025 & 0.0027 & 0.0029 & 0.0033 & 0.0036 & 0.0039 \\
\hline $\mathrm{q}_{\mathrm{e}}(\mathrm{mg} / \mathrm{g})$ & 471 & 467 & 462 & 433 & 395 & 361 & 337 & 304 & 276 & 253 \\
\hline $\begin{array}{l}\mathrm{h} \\
(\mathrm{mg} / \mathrm{g} / \mathrm{min})\end{array}$ & 466 & 437 & 448 & 431 & 389 & 353 & 329 & 304 & 274 & 250 \\
\hline $\mathrm{R}^{2}$ & 0.9992 & 0.9995 & 0.9997 & 0.9997 & 0.9998 & 0.9999 & 0.9999 & 0.9999 & 0.9999 & 0.9999 \\
\hline \multicolumn{11}{|c|}{ Elovich parameters for TFC in $P E$ at $25^{\circ} \mathrm{C}$ and $p H 5$} \\
\hline Dosage & $0.5 \mathrm{~g} / \mathrm{L}$ & $1 \mathrm{~g} / \mathrm{L}$ & $1.5 \mathrm{~g} / \mathrm{L}$ & $2 \mathrm{~g} / \mathrm{L}$ & $2.5 \mathrm{~g} / \mathrm{L}$ & $3 \mathrm{~g} / \mathrm{L}$ & $3.5 \mathrm{~g} / \mathrm{L}$ & $4 \mathrm{~g} / \mathrm{L}$ & $4.5 \mathrm{~g} / \mathrm{L}$ & $5 \mathrm{~g} / \mathrm{L}$ \\
\hline $\begin{array}{l}\text { B } \\
(\mathrm{mg} / \mathrm{g} \cdot \mathrm{min})\end{array}$ & 0.296 & 0.385 & 0.341 & 0.441 & 0.527 & 0.637 & 0.768 & 0.961 & 1.17 & 1.47 \\
\hline $\mathrm{R}^{2}$ & 0.8660 & 0.8185 & 0.8422 & 0.8047 & 0.7922 & 0.7779 & 0.7657 & 0.7565 & 0.7590 & 0.7289 \\
\hline
\end{tabular}

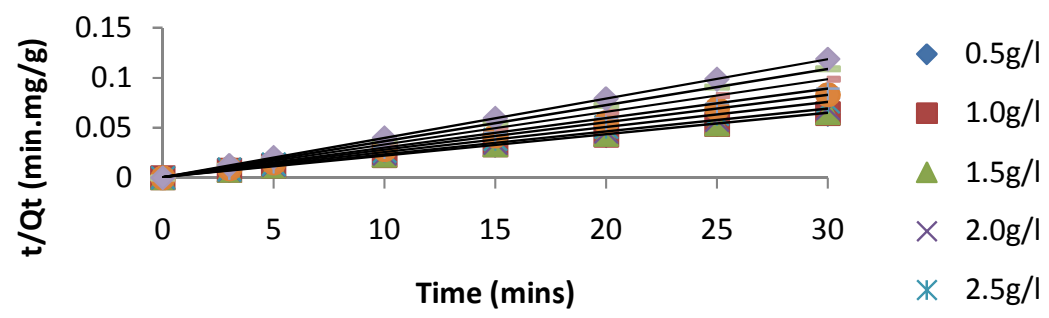

Figure 8. The pseudo-second order kinetic plot for TFC in PE at $25^{\circ} \mathrm{C}$ and $\mathrm{pH} 5$.

Intra-particle diffusion kinetics

Weber and Morris model (Eq. 7) investigated intra-particle diffusion resistance on the process $[29,30]$.

$q_{t}=K_{i d} t^{0.5}$

where $k_{i d}\left(\mathrm{mg} \cdot \mathrm{g}^{-1} \cdot \mathrm{min}^{-0.5}\right)$ is rate constant, $q_{t}\left(\mathrm{mg} \cdot \mathrm{g}^{-1}\right)$ is adsorption capacity at time $\mathrm{t}(\mathrm{min})$.

The logarithmic form of Eq.7 yields Eq. 8:

$\log q_{t}=\log K_{i d}+0.5 \log (t)$

Bull. Chem. Soc. Ethiop. 2016, 30(3) 
A straight line plot of Eq. 8 with positive intercept is a condition for intra-particle diffusion controlled process. The $K_{i d}$ from Figure 9 intercepts are shown in Table 5 for $\mathrm{R}^{2}>0.95$, confirming particle diffusion as a rate limiting step.

Model reliability was tested by diffusion coefficient, $D_{p}$ (Eq. 9) $[29,30]$ :

$D_{p}=\left(0.03 r_{o}^{2}\right) / t_{0.5}$

where $r_{0}\left(4.1425 \times 10^{-13} \mathrm{~cm}\right)$ [23] is the average radius of the TFC particles, and $t_{0.5}(\mathrm{~min})$ is the half-life of the adsorptive process.

If $D_{p}$ is in the range $10^{-11}$ to $10^{-13} \mathrm{~cm}^{2} \cdot \mathrm{s}^{-1}$, then intra-particle diffusion is the rate determining step [30]. Table 5 shows $D_{p}\left(10^{-16}-10^{-22} \mathrm{~cm}^{2} \cdot \mathrm{s}^{-1}\right)$ that are within $10^{-11}$ to $10^{-13} \mathrm{~cm}^{2} \cdot \mathrm{s}^{-1}$ [30] and $\mathrm{R}^{2}>$ 0.96 , thus confirming intra-particle diffusion as the rate determining step. Similar result has been obtained elsewhere [30].

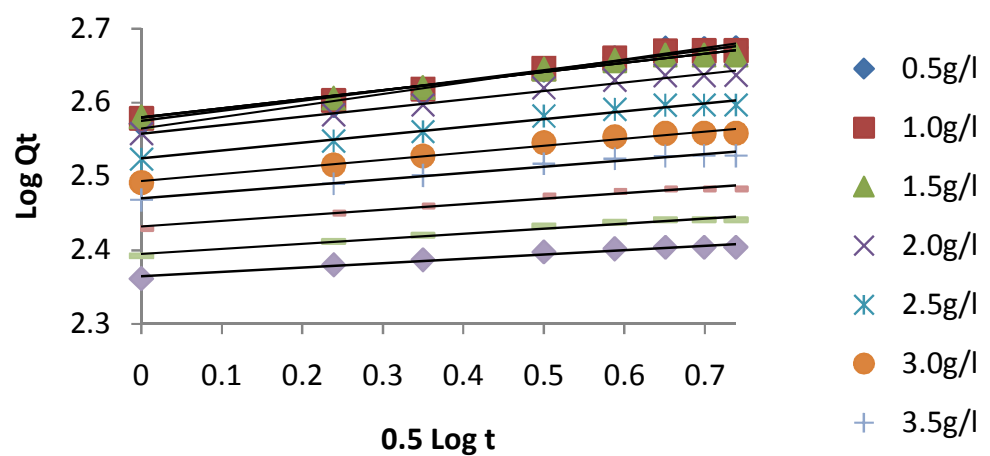

Figure 9. Intra-particle diffusion for TFC in $\mathrm{PE}$ at $25^{\circ} \mathrm{C}$ and $\mathrm{pH} 5$.

Table 5. Intra-particle diffusion parameter for TFC in $\mathrm{PE}$ at $25^{\circ} \mathrm{C}$ and $\mathrm{pH} 5$.

\begin{tabular}{|c|c|c|c|c|c|c|c|c|c|c|}
\hline Dosage & $0.5 \mathrm{~g} / \mathrm{L}$ & $1 \mathrm{~g} / \mathrm{L}$ & $1.5 \mathrm{~g} / \mathrm{L}$ & $2 \mathrm{~g} / \mathrm{L}$ & $2.5 \mathrm{~g} / \mathrm{L}$ & $3 \mathrm{~g} / \mathrm{L}$ & $3.5 \mathrm{~g} / \mathrm{L}$ & $4 \mathrm{~g} / \mathrm{L}$ & $4.5 \mathrm{~g} / \mathrm{L}$ & $5 \mathrm{~g} / \mathrm{L}$ \\
\hline $\begin{array}{l}\mathrm{K}_{\mathrm{id}} \\
\left(\mathrm{mg} / \mathrm{g} / \min ^{0.5}\right)\end{array}$ & 0.1369 & 0.1369 & 0.1235 & 0.1153 & 0.1061 & 0.096 & 0.0855 & 0.0757 & 0.0682 & 0.0593 \\
\hline $\mathrm{Dp}(\mathrm{c}$ & $\begin{array}{c}1.40 \mathrm{x} \\
10^{-16}\end{array}$ & $\begin{array}{c}1.80 \mathrm{x} \\
10^{-16}\end{array}$ & $\begin{array}{c}7.30 \mathrm{x} \\
10^{-17}\end{array}$ & $\begin{array}{c}3.20 \times x \\
10^{-17}\end{array}$ & $\begin{array}{c}2.80 \mathrm{x} \\
10^{-18}\end{array}$ & $\begin{array}{c}4.40 \mathrm{x} \\
10^{-19}\end{array}$ & $\begin{array}{c}2.80 \mathrm{x} \\
10^{-19}\end{array}$ & $\begin{array}{c}4.50 \mathrm{x} \\
10^{-20}\end{array}$ & $\begin{array}{c}7.80 \mathrm{x} \\
10^{-21}\end{array}$ & $\begin{array}{c}4.20 \mathrm{x} \\
10^{-22}\end{array}$ \\
\hline $\mathrm{R}^{2}$ & 0.9829 & 0.9829 & 0.9843 & 0.9833 & 0.9825 & 0.9812 & 0.9786 & 0.9771 & 0.9756 & 0.9688 \\
\hline
\end{tabular}

\section{Boyd kinetics}

Boyd kinetics equations [30] further confirm the rate-controlling step:

$F=1-\frac{6}{\pi^{2}} \exp -\beta t$

$F=q_{e} / q_{t}$

$\beta t=-0.4985-\ln \left[1-\left(\frac{q t}{q e}\right)\right]$

where $q_{t}$ is adsorption capacity at time, $\mathrm{t}, q_{e}$ is adsorption capacity at equilibrium, $\beta t$ is a mathematical function of F.q $q_{t}[30]$. 
Table 6 shows that the $\mathrm{R}^{2}$ from plot of $-\beta t$ against time $>0.98$. Hence, intra-particle diffusion was the rate determining step. Similar result is reported elsewhere [30].

Table 6. Boyd kinetic parameter for TFC in PE at $25^{\circ} \mathrm{C}$ and $\mathrm{pH} 5$.

\begin{tabular}{|c|c|c|c|c|c|c|c|c|c|c|}
\hline Dosage & $0.5 \mathrm{~g} / \mathrm{L}$ & $1 \mathrm{~g} / \mathrm{L}$ & $1.5 \mathrm{~g} / \mathrm{L}$ & $2 \mathrm{~g} / \mathrm{L}$ & $2.5 \mathrm{~g} / \mathrm{L}$ & $3 \mathrm{~g} / \mathrm{L}$ & $3.5 \mathrm{~g} / \mathrm{L}$ & $4 \mathrm{~g} / \mathrm{L}$ & $4.5 \mathrm{~g} / \mathrm{L}$ & $5 \mathrm{~g} / \mathrm{L}$ \\
\hline
\end{tabular}

\begin{tabular}{|l|l|l|l|l|l|l|l|l|l|l|}
$\mathrm{R}^{2}$ & 0.9853 & 0.9901 & 0.9923 & 0.9925 & 0.9995 & 0.9963 & 0.9961 & 0.9978 & 0.9983 & 0.9983 \\
\hline
\end{tabular}

Isotherm analysis

Table 7 indicates the isotherm models while Figures 10a to $\mathrm{c}$ show the equilibrium plots at 25 , 35 and $45^{\circ} \mathrm{C}$, respectively. The isotherm data were subjected to linear and non-linear analyses. The parameters are shown in Table 8 . The values of $\mathrm{R}^{2}$, chi-square $\left(\chi^{2}\right)$ and sum of square error (SSE) show that the data best fitted with the Langmuir model $\left(\mathrm{R}^{2}>0.99, \chi^{2}<1.4\right.$, SSE $\left.<1.6\right)$. The data were also fitted to linear models (Figures not shown). Table 9 indicates best fit for the Langmuir $\left(\mathrm{R}^{2}>0.99, \chi^{2}<0.6, \mathrm{SSE}<0.8\right)$ and followed by Temkin model. Similar results were obtained in this report where Langmuir isotherm dominated. The $\mathrm{Q}_{\max }$ increased with increasing temperature. Similar results are obtained for $\mathrm{K}_{\mathrm{F}}$ and $\mathrm{B}$.

Table 7. The isotherm model used for the analysis of the equilibrium data.

\begin{tabular}{|l|l|c|c|l|l|}
\hline Model & $\begin{array}{l}\text { Non-linear form of the } \\
\text { equation }\end{array}$ & Linear form of the equation & Plots made & $\begin{array}{l}\text { Eq. } \\
\text { No }\end{array}$ & Reference \\
\hline Langmuir & $q_{e}=\left(q_{m} K_{a} C_{e}\right) /\left(1+K_{a} C_{e}\right)$ & $C_{e} / q_{e}=1 /\left(K_{a} q_{m}\right)+C_{e} / q_{m}$ & $C_{e} / q_{e} v s C_{e}$ & 12 & $29-31$ \\
\hline Freundlich & $q_{e}=K_{F} C_{e}{ }^{I / n}$ & $\log q_{e}=\log K_{F}+(1 / n) \log C_{e}$ & $\log q_{e} v s \log C_{e}$ & 13 & $29-32$ \\
\hline Temkin & $q_{e}=R T / B t(\ln K p C e)$ & $q e=(R T / B t) \ln K t+(R T / B t) \ln C e$ & $q_{e} v s \ln C_{e}$ & 14 & 21,25 \\
\hline Frumkin & $q_{e}=A+B \ln \left(C_{e} / q_{e}\right)$ & $q_{e} v s \ln \left(C_{e} / q_{e}\right)$ & & 15 & 33 \\
\hline DRK & $q_{e}=q_{s} \exp \left(-K_{a d} E^{2}\right)$ & $\ln q_{e}-\ln q_{s}-K_{a} d E^{2}$ & $\ln q_{e} v s E^{2}$ & 16 & 29,30 \\
\hline
\end{tabular}

Confirmation of favourability of the adsorptive process

Eq. 17 confirms the favourability of the process for Langmuir [29, 32]:

$R_{L}=\frac{1}{(1+\text { KaCo })}$

It is: (i) unfavourable when $R_{L}>1$, (ii) linear when $R_{L}=1$, (iii) favourable when $0<R_{L}<1$, and (iv) irreversible when $\mathrm{R}_{\mathrm{L}}=0$. For Freundlich isotherm, it is favourable if $\mathrm{n}$ ranges $1-10$. Thus $R_{L}$ and $\mathrm{n}$ values in Tables 8 and 9 indicate favourability. 

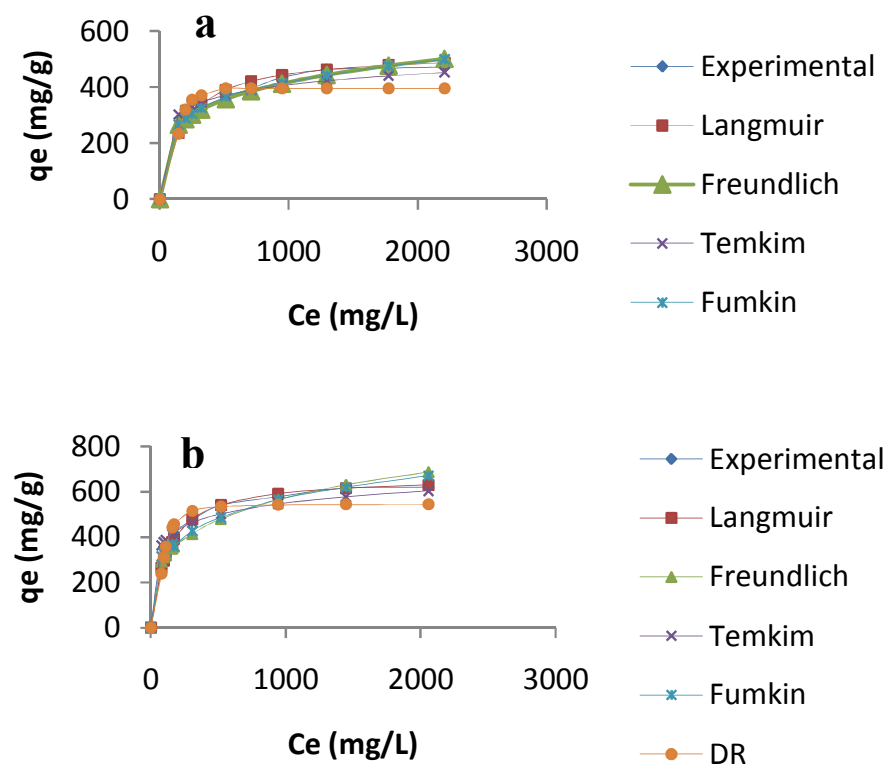

- Experimental

- Langmuir

$\triangle$ Freundlich

$\times$ Temkim

* Fumkin

$\because \mathrm{DR}$

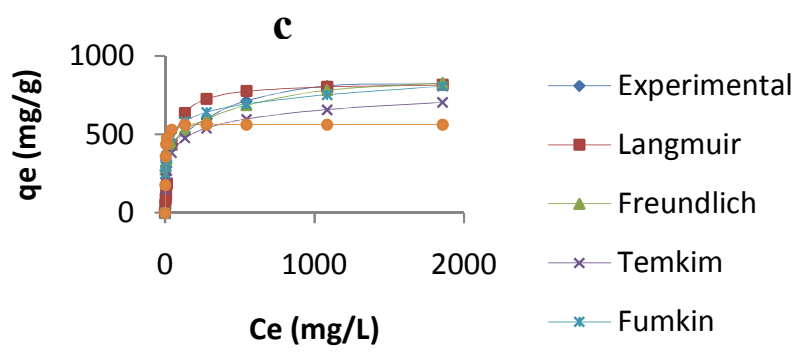

Figure 10. Non-linear isotherm plots of TFC in PE at pH 5 for: (a) 25, (b) 35 and (c) $45^{\circ} \mathrm{C}$.

Adsorption thermodynamics

The $\left(\Delta \mathrm{G}^{\circ}\right),\left(\Delta \mathrm{H}^{\circ}\right)$, and $\left(\Delta \mathrm{S}^{\circ}\right)$, were calculated using Eqs. 18-20, respectively.

$\Delta G^{\circ}=-R T \ln K_{a}$

$\Delta H^{\circ}=R\left[\frac{T_{2} T_{1}}{T_{2}-T_{1}}\right] \ln \frac{K_{a 2}}{K a 1}$

$\Delta S^{\circ}=\frac{\left(\Delta H^{\circ}-\Delta G^{\circ}\right)}{T}$ 
Table 8. The isotherm parameters obtained from non-linear analysis of TFC in PE at pH 5 for Langmuir, Freundlich, Temkin, Frumkin and DRK.

\begin{tabular}{|c|c|c|c|c|c|c|}
\hline Langmuir & $\mathrm{K}_{\mathrm{a}}(\mathrm{L} / \mathrm{mg})$ & $\mathrm{Q}_{\mathrm{m}}(\mathrm{mg} / \mathrm{g})$ & $\mathrm{R}^{2}$ & $\chi^{2}$ & $\mathrm{SSE}(\%)$ & $\mathrm{R}_{\mathrm{L}}$ \\
\hline $25^{\circ} \mathrm{C}$ & 0.0058 & 500 & 0.9975 & 0.597 & 1.58 & 0.06 \\
\hline $35^{\circ} \mathrm{C}$ & 0.0083 & 667 & 0.9965 & 0.625 & 0.788 & 0.043 \\
\hline $45^{\circ} \mathrm{C}$ & 0.024 & 833 & 0.9959 & 1.428 & 0.109 & 0.015 \\
\hline
\end{tabular}

\begin{tabular}{|c|c|c|c|c|c|}
\hline Freundlich & $\mathrm{K}_{\mathrm{F}}(\mathrm{L} / \mathrm{mg})$ & $\mathrm{N}$ & $\mathrm{R}^{2}$ & $\chi^{2}$ & SSE (\%) \\
\hline $25^{\circ} \mathrm{C}$ & 82.8 & 4.27 & 0.9657 & 0.152 & 0.399 \\
\hline $35^{\circ} \mathrm{C}$ & 92.3 & 3.81 & 0.9427 & 0.272 & 0.697 \\
\hline $45^{\circ} \mathrm{C}$ & 226 & 5.74 & 0.9850 & 2.598 & 6.15 \\
\hline
\end{tabular}

\begin{tabular}{|c|c|c|c|c|c|}
\hline Temkin & $\mathrm{K}_{\mathrm{T}}(\mathrm{L} / \mathrm{g})$ & $\mathrm{B}(\mathrm{kJ} / \mathrm{mol})$ & $\mathrm{R}^{2}$ & $\chi^{2}$ & $\mathrm{SSE}(\%)$ \\
\hline $25^{\circ} \mathrm{C}$ & 1.8 & 30.0 & 0.9714 & 0.0062 & 0.0855 \\
\hline $35^{\circ} \mathrm{C}$ & 1.9 & 24.3 & 0.9574 & 0.0151 & 0.276 \\
\hline $45^{\circ} \mathrm{C}$ & 2.2 & 31.5 & 0.9691 & 0.2495 & 1.515 \\
\hline
\end{tabular}

\begin{tabular}{|c|c|c|c|c|c|}
\hline Frumkin & $\mathrm{A}$ & $\mathrm{B}$ & $\mathrm{R}^{2}$ & $\chi^{2}$ & $\mathrm{SSE}$ \\
\hline $25^{\circ} \mathrm{C}$ & 328 & 109 & 0.974 & 8.8195 & 7.34 \\
\hline $35^{\circ} \mathrm{C}$ & 492 & 144 & 0.901 & -28.147 & 17.7 \\
\hline $45^{\circ} \mathrm{C}$ & 721 & 106 & 0.9634 & -42.384 & 133 \\
\hline
\end{tabular}

\begin{tabular}{|c|c|c|c|c|c|}
\hline $\mathrm{DRK}$ & $\mathrm{Qs}(\mathrm{mg} / \mathrm{g})$ & $\mathrm{B}\left(\mathrm{mol}^{2} / \mathrm{kJ}^{2}\right)$ & $\mathrm{R}^{2}$ & $\chi^{2}$ & $\mathrm{SSE}$ \\
\hline $25^{\circ} \mathrm{C}$ & 397 & $-2.00 \times 10^{6}$ & 0.522 & 130429 & 34474 \\
\hline $35^{\circ} \mathrm{C}$ & 549 & -0.0008 & 0.868 & 646 & 1077 \\
\hline $45^{\circ} \mathrm{C}$ & 565 & $-2.00 \times 10^{6}$ & 0.523 & $2.00 \times 10^{6}$ & 2585 \\
\hline
\end{tabular}

Table 9. The isotherm parameters obtained from linear analysis of TFC in PE at pH 5 for Langmuir, Freundlich, Temkin, Frumkin and DRK.

\begin{tabular}{|c|c|c|c|c|c|c|}
\hline Langmuir & $\mathrm{K}_{\mathrm{a}}(\mathrm{L} / \mathrm{mg})$ & $\mathrm{Q}_{\mathrm{m}}(\mathrm{mg} / \mathrm{g})$ & $\mathrm{R}^{2}$ & $\chi^{2}$ & $\mathrm{SSE}(\%)$ & $\mathrm{R}_{\mathrm{L}}$ \\
\hline $25^{\circ} \mathrm{C}$ & 0.0056 & 526 & 0.9986 & 0.597 & 0.757 & 0.062 \\
\hline $35^{\circ} \mathrm{C}$ & 0.0083 & 667 & 0.9997 & 0.633 & 0.786 & 0.043 \\
\hline $45^{\circ} \mathrm{C}$ & 0.024 & 833 & 0.9962 & 0.180 & 0.146 & 0.015 \\
\hline
\end{tabular}

\begin{tabular}{|c|c|c|c|c|c|}
\hline Freundlich & $\mathrm{K}_{\mathrm{F}}(\mathrm{L} / \mathrm{mg})$ & $\mathrm{N}$ & $\mathrm{R}^{2}$ & $\chi^{2}$ & $\mathrm{SSE}(\%)$ \\
\hline $25^{\circ} \mathrm{C}$ & 82.0 & 4.2 & 0.9668 & 0.597 & 0.340 \\
\hline $35^{\circ} \mathrm{C}$ & 94.4 & 3.8 & 0.9518 & 0.267 & 0.710 \\
\hline $45^{\circ} \mathrm{C}$ & 230 & 5.7 & 0.9890 & 2.603 & 5.17 \\
\hline
\end{tabular}

\begin{tabular}{|c|c|c|c|c|c|}
\hline Temkin & $\mathrm{K}_{\mathrm{T}}(\mathrm{L} / \mathrm{mg})$ & $\mathrm{B}(\mathrm{kJ} / \mathrm{mol})$ & $\mathrm{R}^{2}$ & $\chi^{2}$ & $\mathrm{SSE}(\%)$ \\
\hline $25^{\circ} \mathrm{C}$ & 1.6 & 29.0 & 0.9812 & 0.334 & 3.69 \\
\hline $35^{\circ} \mathrm{C}$ & 1.7 & 22.5 & 0.9579 & 0.849 & 7.64 \\
\hline $45^{\circ} \mathrm{C}$ & 1.9 & 30.4 & 0.9701 & 1.559 & 9.79 \\
\hline
\end{tabular}

\begin{tabular}{|c|c|c|c|c|c|}
\hline Frumkin & $\mathrm{A}$ & $\mathrm{B}$ & $\mathrm{R}^{2}$ & $\chi^{2}$ & SSE \\
\hline $25^{\circ} \mathrm{C}$ & 327 & 111 & 0.9644 & 8.60 & 7.14 \\
\hline $35^{\circ} \mathrm{C}$ & 492 & 149 & 0.9040 & -28.7 & 16.8 \\
\hline $45^{\circ} \mathrm{C}$ & 720 & 105 & 0.9654 & -41.0 & 135 \\
\hline
\end{tabular}

\begin{tabular}{|c|c|c|c|c|c|}
\hline $\mathrm{DRK}$ & $\mathrm{Q}_{\mathrm{s}}(\mathrm{mg} / \mathrm{g})$ & $\mathrm{B}\left(\mathrm{mol}^{2} / \mathrm{kJ}^{2}\right)$ & $\mathrm{R}^{2}$ & $\chi^{2}$ & $\mathrm{SSE}$ \\
\hline $25^{\circ} \mathrm{C}$ & 394 & -0.000002 & 0.5256 & 133143 & 3439 \\
\hline $35^{\circ} \mathrm{C}$ & 545 & -0.0008 & 0.8782 & 660 & 1078 \\
\hline $45^{\circ} \mathrm{C}$ & 562 & -0.00001 & 0.5313 & 168687 & 2587 \\
\hline
\end{tabular}

Bull. Chem. Soc. Ethiop. 2016, 30(3) 
Parameters values are presented in Table 10 . Positive $\Delta \mathrm{H}^{\circ}$ indicated endothermicity, while positive $\Delta \mathrm{S}^{\circ}$ pointed to increased randomness $[26,29] . \Delta \mathrm{G}^{\circ}$ values were increasingly negative, indicating increasing feasibility and spontaneity. The process was physiosorption since $\Delta \mathrm{H}^{\circ}$ $(47.3 \mathrm{~kJ} / \mathrm{mol})$ is below the threshold of $40 \mathrm{~kJ} / \mathrm{mol}$. Thus, van der Waals attraction prevailed. A similar result has been reported elsewhere [21].

Table 10. Thermodynamics parameters of TFC in PE.

\begin{tabular}{|c|c|c|c|c|}
\hline $\mathrm{T}(\mathrm{K})$ & $\Delta \mathrm{G}^{\circ}(\mathrm{kJ} / \mathrm{mol})$ & $\Delta \mathrm{H}^{\circ}(\mathrm{kJ} / \mathrm{mol})$ & $\Delta \mathrm{S}^{\circ}(\mathrm{kJ} / \mathrm{mol})$ & $\mathrm{E}_{\mathrm{a}}(\mathrm{J} / \mathrm{mol})$ \\
\hline 298 & -28.8 & & & \\
\hline 308 & -30.8 & 47.3 & 0.256 & 30.0 \\
\hline 318 & -34.6 & & & \\
\hline
\end{tabular}

\section{CONCLUSION}

Particle removal was a function of dosage, $\mathrm{pH}$ and settling time. Optimum efficiency of $97 \%$ was obtained at $\mathrm{pH} 5$ and $2 \mathrm{~g} / \mathrm{L}$. Kinetic data best correlated with the pseudo-second order equation, $\mathrm{q}_{\mathrm{t}}$ increased with increasing temperature. Equilibrium data fitted the Langmuir model best. Thermodynamics showed endothermic and spontaneous process. The adsorptive process was a significant component in the coagulation process. This was shown by significant fitting of coagulation data to adsorption model equations, coupled with high performance of TFC at the experimental conditions.

\section{ACKNOWLEDGEMENTS}

The authors wish to thank the following organization: Department of Chemical Engineering, Nnamdi Azikiwe University, Awka, Nigeria; Department of Chemistry, Stellenbosch University, Stellenbosch, South Africa; Water Resources Center, Texas Tech University, Lubbock, TX, USA; and Fulbright Program, Council for International Exchange of Scholars (CIES), Washington, DC 20005-2403 USA.

\section{REFERENCES}

1. Akyol, A. Desalination 2012, 285, 91.

2. Aydin, S.; Yasin, O.B. Desalin. Water Treat. 2016, 57, 12692.

3. Menkiti, M.C.; Ndaji, C.R.; Ezemagu, I.G.; Oyoh, K. B.; Menkiti, N.U. J. Environ. Chem. Eng. 2015, 3, 1802.

4. Swati, M.; Govindan. V.S. J. Indian Water Works Assoc. 2005, 37, 145.

5. Menkiti, M.C.; Ezemagu, I.G.; Nwonye, C.I.; Ejimofor, M.I. Int. J. Energy Environ. Eng. 2015, Doi 10.1007/S40095-015-0192-Y.

6. Menkiti, M.C.; Nnaji, P.C.; Onukwuli, O.D. Nat. Sci. 2009, 7, 1.

7. Simate, G.S.; Iyuke, S.E.; Ndlovu, S.; Heydenrychb, M. Wat. Res. 2012, 46, 1185.

8. Menkiti, M.C. Studies on the Rapid Coagulation and Flocculation of Coal Washery Effluent: A Turbidimetric Approach, M.Sc Thesis, Nnamdi Azikiwe University, Awka, Nigeria, 2007.

9. Verma S.; Prasad, B.; Mishra, I.M. J. Hazard. Mater. 2010, 178, 1055.

10. Menkiti, M.C.; Nwonye, C.I.; Onyechi, C.A.; Onukwuli, O.D. Adv. Chem. Eng. Sci. 2011, 1, 125.

11. Renault, F.; Sancey, B.; Badot, P.M.; Crini, G. Eur. Polym. J. 2009, 45, 1337.

12. Verma, A.K. Das, R.R.; Bhunia, P. J. Environ. Manage. 2012, 93, 154.

13. Menkiti, M.C.; Onukwuli, O.D. AICHE Journal, 2012, 56, 1303. 
14. Miller, S.M.; Fugate, E.J.; Craver, V.O.; Smith, J.A.; Zimmerman, J.B. Environ. Sci. Technol. 2008, 42, 4274.

15. Clesceri, L.S.; Greenberg, A.E.; Eaton, A.D. Standard Methods for the Examination of Water and Wastewater, 20th Edition, American Public Health Association (APHA): USA; 1999.

16. Feng, Y.; Gong, J.; Zeng, G.; Niu, Q.; Zhang, H.; Niu, C.; Deng, J.; Yan, M. J. Chem. Eng. 2010, 162, 487.

17. Menkiti, M.C.; Ndaji, C.R.; Ezemagu, I.G.; Udammeri, V. J. Disper. Sci. Technol. 2015, 37, 760.

18. Stuart, B.H. Infrared Spectroscopy: Fundamentals and Applications, John Wiley and Sons: New York; 2004.

19. Menkiti, M.C.; Ezemagu, I.G.; Okolo, B.I. Pet. Sci. 2016, 13, 328.

20. Gill, P.; Moghadam, T.; Ranjbar, B. J. Biomol. Tech. 2010, 21, 167.

21. Menkiti, M.C.; Aneke, M.C.; Ejikeme, P.M.; Onukwuli, O.D.; Menkiti, N.U. Springerplus 2014, 3:213.

22. Ramani, K.; Jain, S.C.; Mandal, A.B.; Sekaran, G. Colloids Surf. B: Biointerfaces 2012 97, 254.

23. Ezemagu, I.G. Nephlometric Study of Adsorptive and Non-Adsorptive Components of Coagulation of Produced Water and Paint Effluent Using Bioextracts, M.Sc Dissertation, Nnamdi Azikiwe University, Awka, Anambra State, Nigeria, 2015.

24. Deng, S.; Bai, R. Water SA 2005, 31, 597.

25. Kannan, A.; Thambidurai, S. Bull. Chem. Soc. Ethiop. 2008, 22, 183.

26. Mohan, D.; Singh, K.P.; Singh, V.K. J. Hazard. Mater. B 2006, 135, 280.

27. Wong, Y.C.; Szeto, Y.S.; Cheung, W.H.; Mckay, G. J. Appl. Polym. Sci. 2004, 92, 2054.

28. Khan, M.I.; Khan, M.A.; Zafar, S.; Hussain, S.A. Sch. J. Eng. Tech. 2015, 3, 741.

29. Adeno, F.; Mulugeta, E.; Zewge, F.; Chebude, Y. Bull. Chem. Soc. Ethiop. 2014, 28, 215.

30. Debnath, S.; Ghosh, U.C. J. Chem. Thermodyn. 2008, 40, 67.

31. Ahmet, S.; Ömer, I. Bull. Chem. Soc. Ethiop. 2006, 20, 259.

32. Qin, L.; Jianping, Z.; Wenyi, Z.; Mingmei, W.; Jun Z. Bull. Chem. Soc. Ethiop. 2008, 22, 19.

33. Volkova-Gugeshashvili, M.I.; Volkov, A.G.; Markin V.S.R. J. Electrochem. 2006, 42, 1073. 